\title{
Effect of Reaction Between Mercury and Oxygen Upon Polarographic Waves of Certain Metals at Small Concentrations
}

\author{
By Edgar Reynolds Smith, John Keenan Taylor, and Roberta Evelyn Smith
}

\begin{abstract}
Polarographic waves of certain metals, notably of lead, zinc, copper, cobalt, and nickel in dilute neutral solutions, diminish progressively with time in the presence of mercury and air. This behavior is not to be explained by adsorption, as has previously been supposed, but by a reaction between mercury, water, oxygen, and the ions of the metallic salt which, in some instances, precipitates the metal from solution in the form of its hydroxide. This reaction is

$$
2 \mathrm{Hg}+\mathrm{H}_{2} \mathrm{O}+1 / 2 \mathrm{O}_{2}+\mathrm{MCl}_{2}=\mathrm{Hg}_{2} \mathrm{Cl}_{2}+\mathrm{M}(\mathrm{OH})_{2},
$$

in which $M$ represents the metal. Recognition of this reaction and precautions to exclude it are essential for accurate polarographic determinations of small amounts of heavy metals.
\end{abstract}

\section{Introduction}

The polarographic method has been used for the determination of small amounts of metals in ores and alloys [1, 2, 3, 4], ${ }^{1}$ plant ashes [5], biological materials [6], samples collected in industrial hygiene studies [7, 8], mineral waters [9], and other materials. Many references could be cited, but these suffice for typical examples. The presence of an unsuspected systematic error in such determinations might lead to expensive mistakes in the value of an ore or the composition of an alloy, or might cause unfortunate consequences through the approval of unsafe respiratory equipment. For example, if a polarographic analysis for the amount of lead in fumes were to give a negative result when lead was actually present, serious harm to the health of workers could result.

During the course of some work on the amount of lead that might enter a cup of tea from certain glazes, the polarographic waves produced by small

\footnotetext{
1 Figures in brackets indicate literature references at the end of this paper.
}

concentrations of lead in neutral solutions were observed to decrease progressively to the point of extinction when the solutions were allowed to stand in contact with mercury and air. This behavior must have been found by others, since Kolthoff and Lingane [10], in their review of principles and applications of the polarographic method, say:

"Adsorption of electroreducible ions (particularly heavy-metal ions) by the glass wall of the cell must be prevented. Such adsorption may be particularly marked when dealing with very small

\section{Contents}

I. Introduction ....... 151

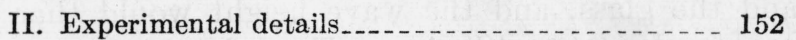

III. Results and conclusions.......... 152

IV. References......... 155 
concentrations of heavy-metal ions (e. g. micropolarographic determination of lead ions), but it can usually be prevented by acidifying the solution."

However, an investigation of the matter has led us to conclude that the effect is not one of adsorption but instead is the result of a chemical reaction similar to the reaction

$$
2 \mathrm{Ag}+2 \mathrm{HCl}+1 / 2 \mathrm{O}_{2}=2 \mathrm{AgCl}+\mathrm{H}_{2} \mathrm{O},
$$

which is known to disturb the potential of the silver-silver-chloride electrode [11, 12]. According to this analogy, the reaction that causes the heavy-metal ion to disappear from solution in the polarographic cell is
$2 \mathrm{Hg}+\mathrm{H}_{2} \mathrm{O}+1 / 2 \mathrm{O}_{2}+\mathrm{MCl}_{2}=$

$$
\mathrm{Hg}_{2} \mathrm{Cl}_{2}+\mathrm{M}(\mathrm{OH})_{2} \text {, }
$$

in which $\mathrm{M}$ represents the heavy metal. This reaction probably occurs in the two stages

$$
\mathrm{MCl}_{2}+2 \mathrm{H}_{2} \mathrm{O}=\mathrm{M}(\mathrm{OH})_{2}+2 \mathrm{HCl}
$$

and

$$
2 \mathrm{Hg}+2 \mathrm{HCl}+1 / 2 \mathrm{O}_{2}=\mathrm{Hg}_{2} \mathrm{Cl}_{2}+\mathrm{H}_{2} \mathrm{O},
$$

the net result of which is expressed by eq 1 .

The experimental work on which is based the conclusion that the effect is one of chemical reaction rather than adsorption is reported in this paper.

\section{Experimental Details}

Two polarographs of the photographic recording type were used. One of these was the model VIII instrument of V. \& J. Nejedly, Prague, Czechoslovakia, described in a previous paper [13] and the other a Sargent-Heyrovsky model XII instrument. The electric measuring circuits of both were calibrated by measuring the potential drop across a standard resistor, which was substituted for the polarographic cell.

The dropping-mercury electrode used in most of the work was made by sealing a piece of capillary tubing of approximately $0.05-\mathrm{mm}$ bore to a reservoir of large cross section so that no significant decrease in the driving head occurred during an operational period of about 1 hour. Periodic addition of mercury sufficed to maintain constant to better than 1 percent the mass-flow from the electrode. Frequent measurements of the droptime and the mass-flow were taken to make sure that conditions were comparable during a series of measurements.
The cells were of the familiar Erlenmeyer type and provided for inert gas to flow through the solution before and over the solution during measurements, to exclude oxygen. The nitrogen used for this purpose was freed from oxygen by passage over copper heated to $450^{\circ} \mathrm{C}$ and then saturated with water vapor before introduction into the cell to minimize concentration errors arising from evaporation.

For the most part, stock solutions were made by dissolving in acid known quantities of the pure metal, evaporating to dryness, and diluting with water to a known volume. Where this was not feasible, salts of known purity were used. These stock solutions were diluted quantitatively to the concentration desired for a particular experiment. Sufficient quantities were prepared at any one time to provide for all the measurements of a particular series so that errors could not occur from differences in composition of the solutions. Maxima in the waves were suppressed by the addition of 0.01 percent of gelatin to the solutions.

\section{Results and Conclusions}

If the effect were one of adsorption, repeated pipetting out and refilling the cell with fresh solution would finally establish the adsorption equilibrium between a solution of the original composition and the glass, and the wave height would then remain constant with time. To make this experiment, $3 \mathrm{ml}$ of a solution containing $10^{-5} \mathrm{~g}$ of lead and $0.025 \mathrm{~g}$ of potassium chloride was allowed to stand over the pool of mercury in a polarographic cell. At intervals the air was displaced by nitrogen and a polarogram taken. Between these intervals air was allowed to diffuse into the solution. The lead wave progressively decreased and practically disappeared within 24 hours. The 
solution was then pipetted out, fresh solution of the original composition put in the cell, and the test repeated. After a number of such refillings the lead wave continued to disappear just as rapidly as for the first filling, with no indication of the supposed adsorption attaining an equilibrium. In another experiment, a portion of solution of the same composition was allowed to stand in contact with crushed Pyrex glass for 24 hours before introduction into the cell. The wave obtained for the lead was then no different from that exhibited by a portion of the same solution which had not been in contact with ground glass. If adsorption had occurred, the lead wave would have been smaller.

Portions of a solution containing about $7 \times 10^{-6}$ $\mathrm{g}$ of zinc and $13 \times 10^{-6} \mathrm{~g}$ of cadmium per milliliter in $0.1 \mathrm{~N}$ potassium chloride were put into three Pyrex flasks. One flask was nearly filled with ground Pyrex glass, one contained several milliliters of mercury, and the other was clear. After standing in these flasks for 24 hours in contact with air, the solutions were poured into cells and polarograms were made. The wave heights obtained were as follows:

\begin{tabular}{|c|c|c|}
\hline \multirow{2}{*}{ Flask } & \multicolumn{2}{|c|}{ Height of wave } \\
\cline { 2 - 3 } & $\mathrm{Cd}$ & $\mathrm{Zn}$ \\
\hline & & \\
& $m m$ & $m m$ \\
Clear_......... & 25.0 & 23.6 \\
Crushed glass_..... & 24.2 & 23.4 \\
Mercury _........ & 21.6 & 3.0 \\
& & \\
\hline
\end{tabular}

Two portions of the same initial solution were placed in cells with pools of mercury for anodes and polarograms of the wave heights were taken. Then air was bubbled through one of these for 5 hours, and nitrogen was bubbled through the other for 24 hours. Polarograms were taken, and from these it was found that the zinc wave had practically disappeared in the former but had decreased by only 8 percent in the latter. The cadmium wave remained practically the same in both cells.

In all cases it was found that the original wave heights were restored by the addition of a small amount of acid, which has the effect of preventing or reversing the reaction expressed by eq 2 . As long as acid is present hydrolysis does not occur, but according to eq 3 , hydrochloric acid is con- sumed by mercury and oxygen to form mercurous chloride and water. Thus, if oxygen is not excluded, in acidic solution the hydrogen wave must first decrease to extinction before hydrolysis begins to affect the wave of a metallic ion. A solution containing cadmium and zinc was acidified with hydrochloric acid so that the waves of hydrogen and of the two metals could be recorded consecutively on the same polarogram. The solution was exposed to air and polarograms were made at intervals. The hydrogen wave decreased progressively from an initial height of about $23 \mathrm{~mm}$ to complete disappearance after little more than 75 minutes. Meanwhile the waves of cadmium and zinc remained constant within experimental error. During this time the surface of the mercury became coated with a layer of calomel, which reduced the effective exposed area of the mercury. For this reason, the wave of zinc did not decrease very rapidly after the acid had disappeared. Air was then bubbled through the solution for 2 hours, and the wave of zinc decreased to $3.5 \mathrm{~mm}$ from an initial height of about $11 \mathrm{~mm}$. The wave of cadmium remained unchanged. These results are summarized in table 1.

TABLE 1.-Effect of oxygen when acid is present

\begin{tabular}{|c|c|c|c|}
\hline \multirow{2}{*}{ Time of exposure to air } & \multicolumn{3}{|c|}{ Wave heights } \\
\hline & H & $\mathrm{Zn}$ & Cd \\
\hline Minules & $m m$ & $m m$ & $m m$ \\
\hline $0 \ldots \ldots \ldots \ldots$ & 22.8 & 10.4 & 10.7 \\
\hline $15 \ldots$ & 14.6 & 11.3 & 10.5 \\
\hline $45 \ldots$ & 8.8 & 12.5 & 10.8 \\
\hline $75 \ldots$ & 3. 0 & 10.6 & 11.0 \\
\hline $195 \ldots$ & 0.0 & 11.4 & 10.4 \\
\hline Air bubbled for 120 minutes more. & .0 & 3.5 & 10.6 \\
\hline
\end{tabular}

If the effect is caused by the chemical reactions represented by eq 1 and 2, the minimum height to which a wave decreases should depend upon the solubility of the hydroxide of the metal in question. Unfortunately, there are no data for the solubility of these heavy metal hydroxides in potassium chloride solutions and even such data as exist for pure water appear to be inconsistent and unreliable. Also, eq 1, 2, and 3 are intended to represent the principle of the effect involved and not the exact mechanism operating in every case. For example, the same principle gives an explanation of why the effect does not occur when the supporting electrolyte is potassium nitrate 
instead of potassium chloride. For nitrate solutions, eq 3 becomes

$$
2 \mathrm{Hg}+2 \mathrm{HNO}_{3}+1 / 2 \mathrm{O}_{2}=2 \mathrm{HgNO}_{3}+\mathrm{H}_{2} \mathrm{O} .
$$

Mercurous nitrate in dilute solution, however, hydrolyzes to give a basic precipitate, $\mathrm{Hg}_{2}(\mathrm{OH})$ $\mathrm{NO}_{3}$ and possibly some $\mathrm{Hg}_{2} \mathrm{O}$, with sufficient affinity to prevent the hydrolysis of zinc nitrate and the precipitation of zinc hydroxide. If a little solid mercurous nitrate is added to a saturated solution of zinc hydroxide in contact with excess solid zinc hydroxide, a large polarographic wave for zinc is actually obtained. The principle of this reaction is expressed by the equation,

$$
\mathrm{Zn}(\mathrm{OH})_{2}+2 \mathrm{HgNO}_{3}=\mathrm{Zn}\left(\mathrm{NO}_{3}\right)_{2}+\mathrm{Hg}_{2} \mathrm{O}+\mathrm{H}_{2} \mathrm{O},
$$

from which it is clear why the waves do not disappear in solutions of nitrates.

The behavior of several uther metallic ions in neutral solutions of potassium chloride in the presence of air and mercury was also studied with results which are summarized in figure 1. Of these ions, thallium, manganese, and cadmium undergo little or no change even on prolonged contact. The waves for cobalt and copper, like those for zinc and lead, show rapid decreases, while the results for nickel are intermediate. The rate of decrease of a wave in any instance is, of course, dependent upon such factors as the area of the mercury surface, the amount of stirring, and the concentration of the ion. Under comparable conditions, the rates of decay are approximately in the order of the hydrolysis constants of the metallic ions, in further confirmation of the mechanism of chemical reaction rather than adsorption.

The rate of decrease of wave height for a given metallic ion depends markedly on its concentration. With concentrations of about $10^{-4} \mathrm{~g} / \mathrm{ml}$ it was found that the lead and zinc waves decrease by only about 10 percent in 24 hours in contrast to the larger rates, shown in figure 1, for more dilute solutions of these ions. Errors of 10 to 20 percent have been noted in polarographic determinations of lead in neutral solutions when exposed to mercury for the short time necessary to expel oxygen from the solutions. Since the effect does not occur when the supporting electrolyte is acidic, it is safer to make polarographic measure- ments of dilute solutions of heavy metallic ions in acidic rather than in neutral media when the anode is a pool of mercury. In cases where the reduction wave of hydrogen interferes and acidic solutions cannot be used, it is possible to avoid the effect by preliminary elimination of oxygen from the solution before contact with mercury, by the use of an external anode [14] or of a silversilver-chloride anode wound in spiral around the dropping-mercury cathode [15], or with a cell of the design devised by Lingane and Laitinen [16].

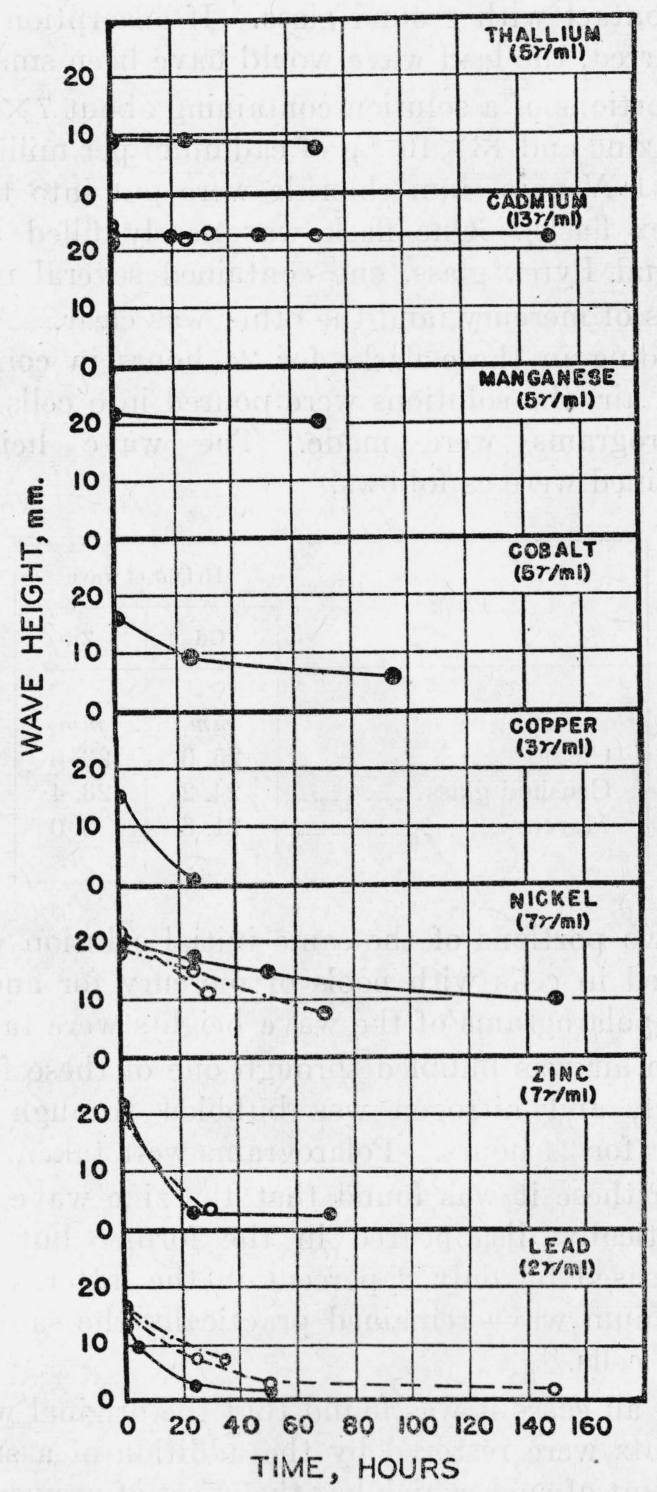

Frgure 1.-Changes in wave heights with time. The open and shaded circles represent different experiments. 


\section{Ref erences}

[1] M. Straumanis and A. Dravnieks, Z. Anal. Chem. 120, 168 (1940).

[2] A. C. Coates and R. Smart, J. Soc. Chem. Ind. 60, 249 (1941).

[3] R. C. Hawkins and H. G. Thode, Ind. Eng. Chem., Anal. Ed. 16, 71 (1944).

[4] I. M. Kolthoff and G. Matsuyama, Ind. Eng. Chem., Anal. Ed. 17, 615 (1945).

[5] P. R. Stout, J. Levy, and L. C. Williams, Collection Czechoslov. Chem. Commun. 10, 129, 136 (1938).

[6] E. Hamamoto, Collection Czechoslov. Chem. Commun. 6, 325 (1934).

[7] F. L. Feicht, H. H. Schrenk, and C. E. Brown, U. S. Bur. Mines, Rept. Investigations 3639, 20 pp. (1942).

[8] L. Levine, J. Ind. Hyg. Toxicol. 27, 171 (1945).
[9] K. Heller, G. Kuhla, and F. Machek, Microchemie 18, 193 (1935); 23, 78 (1937).

[10] I. M. Kolthoff and J. J. Lingane. Chem. Rev. 24, 82 (1938).

[11] E. Güntelberg, Z. physik. Chem. 123, 199 (1926).

[12] J. K. Taylor and E. R. Smith, J. Research NBS 22, 307 (1939) RP1183.

[13] H. Matheson, H. S. Isbell, and E. R. Smith, J. Research NBS 28, 100 (1942) RP1448.

[14] D. N. Hume and W. E. Harris, Ind. Eng. Chem., Anal. Ed. 15, 465 (1943).

[15] J. J. Lingane, Ind. Eng. Chem., Anal Ed. 16, 329 (1944).

[16] J. J. Lingane and H. A. Laitinen, Ind. Eng. Chem., Anal. Ed. 11, 504 (1939).

Washington, June 24, 1946. 